\title{
Oxidation reactions of 1,3-diphenylpropane-1,3-dione
}

\author{
MEDHA RELE ${ }^{1}$, B S PATRO ${ }^{2}$, S ADHIKARI $^{1}$, G P KALENA $^{2}$, \\ $S_{S}$ CHATTOPADHYAY ${ }^{2}$ and T MUKHERJEE ${ }^{1 *}$ \\ ${ }^{1}$ Radiation Chemistry and Chemical Dynamics Division, and \\ ${ }^{2}$ Bio-Organic Division, Bhabha Atomic Research Centre, Mumbai 400 085, \\ India \\ e-mail: mukherji@magnum.barc.ernet.in
}

\begin{abstract}
The free radical scavenging properties and possible antioxidant activity of 1,3-diphenylpropane-1,3-dione (1) are reported. Pulse radiolysis technique was employed to study the one-electron oxidation of 1 with various radicals viz. $\mathrm{CCl}_{3} \mathrm{O}_{2}{ }^{*}$, $\mathrm{N}_{3}{ }^{\circ}$ and ${ }^{\circ} \mathrm{OH}$ in homogeneous aqueous solution. All these radicals reacted with 1 under ambient conditions at almost diffusion controlled rates producing transient species with an absorption maximum around $420 \mathrm{~nm}$ that decayed at first order rates. The transient absorption peak was shifted in the case of $\mathrm{CCl}_{3} \mathrm{OO}^{\circ}$ radical reaction with 1 due to change in the polarity of the medium. Formation of a stable product with a broad absorption band starting from $400 \mathrm{~nm}$ and cut off at $230 \mathrm{~nm}$ was observed in the oxidation of 1 with ${ }^{\circ} \mathrm{OH}$ and ${ }^{\circ} \mathrm{N}_{3}$ radicals. In a biological system also, $\mathbf{1}$ showed significant inhibitory activity against $\mathrm{Fe}^{2+}$-mediated lipid peroxidation. Based on these observations, a suitable mechanism for the oxidation of $\mathbf{1}$ has been proposed.
\end{abstract}

Keywords. $\beta$-Diketone; pulse radiolysis; oxidation; lipid peroxidation.

\section{Introduction}

A wide array of phenolic substances, particularly those present in dietary and medicinal plants, has been reported to possess substantial anti-oxidative and anti-inflammatory properties, examples being curcuminoids, gingeroids etc. Numerous studies have been conducted on the anti-cancer activity of curcumin. ${ }^{1-5}$ Recently, we have shown that in the iron-independent peroxidation, the ginger-derived curcuminoid [6]-dehydrogingerdione possesses comparable antioxidant activity ${ }^{6}$ to curcumin due to its greater-membrane binding capacity.

Of late, the mechanism of antioxidant action of the curcuminoids has been the matter of considerable debate due to the possible involvement of their constituent phenolic as well as $\beta$-diketone groups in scavenging the oxidizing radicals. It is speculated ${ }^{7}$ that a considerable percentage of their antioxidant activity is due to the facile methylenic hydrogen transfer from the $\beta$-diketone moiety. In contrast, using classical methods, Ross et $a l^{8}$ have put forward a phenolic chain-breaking antioxidant mechanism for curcumin. Very recently, based on evidence from kinetic techniques like laser flash photolysis and pulse radiolysis, it has been proposed ${ }^{9}$ that though a methylenic radical is produced initially at the $\beta$-diketone moiety, the radical centre shifts its location to the phenolic site via a hydrogen transfer. In our study, the participation of both the designated functional groups in the antioxidant action of [6]-dehydrogingerdione has been established. ${ }^{6}$

*For correspondence 
However, formation of the carbon-centred methylenic radical could not be demonstrated unequivocally due to the overlap of its absorptions with the bleaching spectrum due to depletion of the parent compound.

The present study was undertaken for further confirmation of the role of the $\beta$-diketone group. For this, 1,3-diphenylpropane-1,3-dione (1) which is devoid of any phenolic group was chosen as the model $\beta$-diketone substrate and its reactions with $\mathrm{CCl}_{3} \mathrm{O}_{2}{ }^{\bullet}$ (a model peroxyl radical), $\mathrm{N}_{3}{ }^{\bullet}$ and the physiologically relevant ${ }^{\circ} \mathrm{OH}$ radical have been studied, primarily using the pulse radiolysis technique. The transients produced in these reactions were followed and the rate constants for the reactions were determined. The transients were subsequently used in elucidating the detailed mechanism for oxidation reactions. The measured rate constants were not mere radiation chemical parameters but reflected on the efficiency of $\mathbf{1}$ in scavenging free radicals and helped in understanding the ease with which the possible competing reactions occur. In addition, the protective activity of 1 against $\mathrm{Fe}^{2+}$-induced lipid peroxidation of rat brain homogeneate was also carried out to test its antioxidant efficacy in a biological test system.

\section{Materials and methods}

\subsection{Chemicals}

Glutathione (Aldrich, USA) and trichloroacetic acid (TCA) (Thomas Baker, India) were used as received. 2-Thiobarbituric acid (TBA), vitamin $\mathrm{C}$ and ferrous ammonium sulfate were procured from Himedia Lab. Pvt. Ltd., India and used as received. All other chemicals were of AR grade. The experiments were conducted in freshly de-ionised 'nanopure' water (conductivity $<0.06 \mu \mathrm{S} \mathrm{cm}^{-1}$, Barnstead nano-pure cartridge filtration system). Suitable controls were used for the bioassay. Compound $\mathbf{1}$ was synthesised by condensing equimolar amounts of acetophenone and ethyl benzoate in the presence of $\mathrm{NaOEt}$ as the base in ether. It was characterised by IR and ${ }^{1} \mathrm{H}$ NMR spectra. The purity of the compound was assessed by HPLC analysis (RP-18 column) which showed a single peak.

\subsection{Methods}

2.2a Pulse radiolysis: The pulse radiolysis system using $7 \mathrm{MeV}$ electrons has been described earlier. ${ }^{10}$ The dosimetry was carried out using an air-saturated aqueous solution containing $5 \times 10^{-2} \mathrm{~mol} \mathrm{dm}^{-3} \quad \mathrm{KSCN} \quad\left(G \varepsilon=23,889 \mathrm{dm}^{3} \mathrm{~mol}^{-1} \mathrm{~cm}^{-1}\right.$ per $100 \mathrm{eV}$ at $500 \mathrm{~nm}^{11}$ ). The kinetic spectrophotometric detection system covered the wavelength range from 250 to $800 \mathrm{~nm}$. The optical path length of the cell was $1.0 \mathrm{~cm}$. The width of the electron pulse was 50 or $500 \mathrm{~ns}$ as per requirement and the dose was $16 \mathrm{~Gy}$ or as specified. Equimolar $\left(5 \times 10^{-3} \mathrm{~mol} \mathrm{dm}^{-3}\right) \mathrm{HPO}_{4}^{2-}$ and $\mathrm{H}_{2} \mathrm{PO}_{4}^{-}$were used to prepare solutions of $p \mathrm{H} \mathrm{6.8.} \mathrm{Other} p \mathrm{H}$ values were obtained by adding $\mathrm{NaOH}$ or $\mathrm{HClO}_{4}$. Alkaline $p \mathrm{H}$ was obtained by adding $\mathrm{NaOH}$ only. High purity (>99.9\%) $\mathrm{N}_{2}$ and/or $\mathrm{N}_{2} \mathrm{O}$, both from British Oxygen Company (India) Pvt. Ltd. were used as per requirement.

Irradiation of the reaction medium leads to the following reactions.

$$
\begin{aligned}
& \mathrm{H}_{2} \mathrm{O} \\
& e_{\mathrm{aq}}{ }^{-}+\mathrm{N}_{2} \mathrm{O}+\mathrm{H}_{2} \mathrm{O} \rightarrow e_{\mathrm{aq}}{ }^{-}, \mathrm{H}^{\bullet},{ }^{\bullet} \mathrm{OH}+\mathrm{OH}^{-}+\mathrm{H}_{2}, \mathrm{H}_{2} \mathrm{O}_{2},
\end{aligned}
$$




$$
{ }^{\bullet} \mathrm{OH}+\mathrm{N}_{3}^{-} \rightarrow \mathrm{OH}^{-}+\mathrm{N}_{3} \cdot
$$

The bimolecular rate constants were calculated by plotting the pseudo-first order rates of formation of the transients against the concerned solute concentrations. The uncertainty in the measurement of bimolecular rate constants was $\pm 10 \%$.

2.2b Lipid peroxidation: Rat brain homogenate, prepared from the brains of freshly killed Wistar rats, was subjected to $\mathrm{Fe}^{2+}$-induced lipid peroxidation as described earlier ${ }^{12}$ with minor modifications. Briefly, the total reaction mixture $(1.0 \mathrm{ml})$ contained $p \mathrm{H} 7.4$ tris- $\mathrm{HCl}$ buffer $\left(1.25 \times 10^{-1} \mathrm{~mol} \mathrm{dm}{ }^{-3}\right)$, brain homogenate $(0.5 \mathrm{mg}$ protein $/ \mathrm{ml})$ with or without the test compound. The reaction was triggered by the addition of ferrous ammonium sulfate $\left(2.0 \times 10^{-5} \mathrm{~mol} \mathrm{dm}^{-3}\right)$ and vitamin $\mathrm{C}\left(2.0 \times 10^{-4} \mathrm{~mol} \mathrm{dm}^{-3}\right)$ followed by incubation of the mixture at $37^{\circ} \mathrm{C}$ for $30 \mathrm{~min}$. The reaction was terminated by addition of $2 \mathrm{ml}$ of TBA-TCA-HCl $\left(0.37 \%\right.$ TBA, $2.8 \%$ TCA, $\left.0.25 \mathrm{~mol} \mathrm{dm}^{-3} \mathrm{HCl}\right)$ solution and boiling the mixture at $100^{\circ} \mathrm{C}$ for $10 \mathrm{~min}$. The extent of lipid peroxidation was assessed from the amount of thiobarbituric acid reactive substrates (TBARS) produced, which was spectrophotometrically read at $532 \mathrm{~nm}$.

\section{Results and discussion}

\subsection{Ground state absorption study}

Figure 1 shows the change in absorption of $\mathbf{1}$ in aqueous solution as a function of $p \mathrm{H}$ in the $p \mathrm{H}$ range of 2 to 12 . With increasing $p \mathrm{H}$ of the solution the intensity of the absorption at $\sim 365 \mathrm{~nm}$ increased while that at $\sim 320 \mathrm{~nm}$ decreased and an isosbestic point at $340 \mathrm{~nm}$ was observed. From this, existence of $\mathbf{1}$ in two tautomeric (keto and enol) forms (scheme 1) at the two extreme $p \mathrm{H}$ levels was inferred.

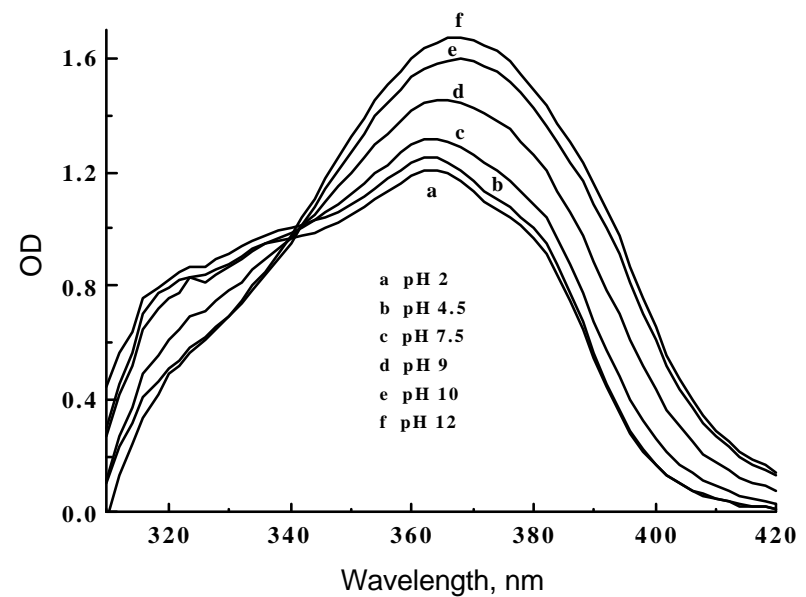

Figure 1. Ground state absorption spectra of a solution of $1 \cdot 0 \times 10^{-4} \mathrm{moldm}^{-3}$ of $\mathbf{1}$ at different $p \mathrm{H}$ levels in $40 \%$ propanol-2-ol/10\% acetone/50\% water. 
<smiles>O=C(CC(=O)c1ccccc1)c1ccccc1</smiles>

Keto-form<smiles>CCOC(=O)C(C(=O)c1ccccc1)c1ccccc1</smiles>

Products<smiles>O=C(C=Cc1ccccc1)c1ccccc1</smiles>

Enol-form

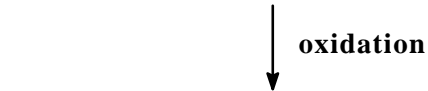<smiles>[CH]C</smiles><smiles>O=C(C=C(O)c1ccccc1)c1ccccc1</smiles>

Scheme 1.

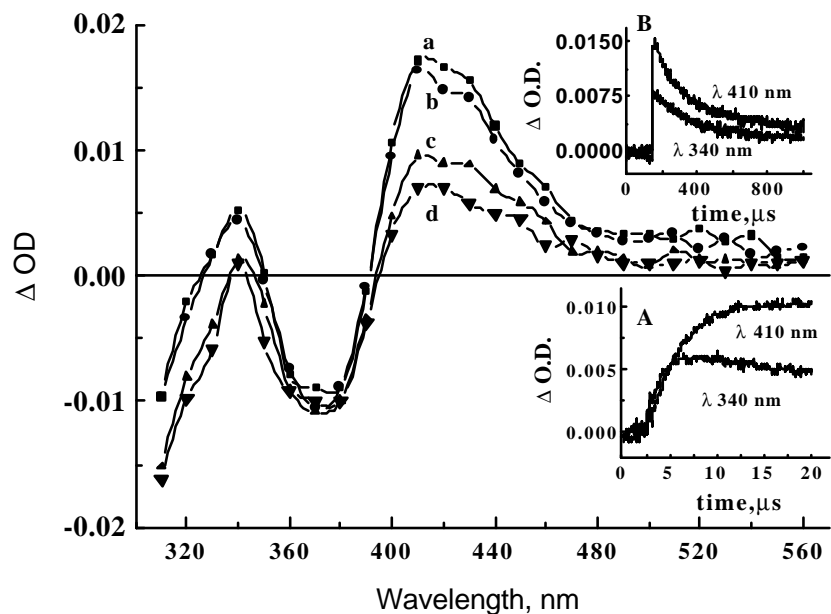

Figure 2. Transient absorption spectrum obtained from $\mathrm{N}_{2} \mathrm{O}$-saturated aqueous solution containing $1\left(1 \times 10^{-4} \mathrm{~mol} \mathrm{dm}^{-3}\right)$ at $p \mathrm{H} 9$ after the electron pulse at (a) $20 \mu \mathrm{s}$, (b) $50 \mu \mathrm{s}$, (c) $200 \mu \mathrm{s}$ and (d) $400 \mu \mathrm{s}$. Insets: The absorbance (OD) vs time plot for the formation (inset A) and decay (inset B) of the radicals produced in the reaction of 1 with ${ }^{\bullet} \mathrm{OH}$ radical.

\subsection{Reaction with the hydroxyl radical}

Hydroxyl radical was found to react with 1 to give absorption maximum at around $420 \mathrm{~nm}$ at $20 \mu \mathrm{s}$ after the electron pulse with a small peak at $340 \mathrm{~nm}$ and a bleaching in the ground state absorption around $375 \mathrm{~nm}$ (figure 2). When the reaction was followed at a higher time scale, a recovery in the bleaching was also observed (not shown in the figure). The bimolecular rate constants for the formation of the peak at $420 \mathrm{~nm}$ at $p \mathrm{H} 9$ was $1 \times 10^{10} \mathrm{dm}^{3} \mathrm{~mol}^{-1} \mathrm{~s}^{-1}$. Though the formation rate constants of the other peak (at $340 \mathrm{~nm}$ ) was similar at the very early stage, it was observed that the absorption peak at $340 \mathrm{~nm}$ started decaying after $6 \mu \mathrm{s}$, while that at $410 \mathrm{~nm}$ continued to build up to $20 \mu \mathrm{s}$. This suggested that in the initial step, ${ }^{\circ} \mathrm{OH}$ radical might possibly be forming (inset A of 
figure 2) an adduct $\left(\lambda_{\max } 340 \mathrm{~nm}\right)$ as well as a radical $\left(\lambda_{\max } 420 \mathrm{~nm}\right)$ simultaneously. Later, a part of the adduct gets transformed into the radical. Both these events happen at the very initial stage which is followed by their decay (inset B of figure 2) almost at the same rate over a time scale of $1 \mathrm{~ms}$. Based on the structure of $\mathbf{1}$, we envisaged that the species absorbing at $420 \mathrm{~nm}$ would be the carbon-centered radical formed by hydrogen abstraction from the methylenic group of its $\beta$-diketone moiety. Similar carbon-centered radical from curcumin was reported to appear at around $490 \mathrm{~nm}^{7}$ The blue shift of the observed absorption peak $(420 \mathrm{~nm})$ in the present case might be due to the fact that compound $\mathbf{1}$ is a relatively smaller molecule and is less conjugated. The reaction of $\mathbf{1}$ with ${ }^{\circ} \mathrm{OH}$ radical at $p \mathrm{H} 8$ also showed similar absorption spectra with a negligible reduction in the rate constant. Thus, within this $p \mathrm{H}$ range, the site of ${ }^{\bullet} \mathrm{OH}$ radical attack to the molecule appeared to remain same.

\subsection{Reaction with the azide radical}

The azide radical is known to react selectively with organic molecules to give the corresponding one-electron oxidized radical species. Compound 1 was found to react with this radical at $p \mathrm{H} 8$ to give a spectrum showing transient absorption maximum at $410 \mathrm{~nm}$ with a shoulder at around $310 \mathrm{~nm}$ (figure 3). The bimolecular rate constant for the formation of the absorption peak at $410 \mathrm{~nm}$ was $1.7 \times 10^{9} \mathrm{dm}^{3} \mathrm{~mol}^{-1} \mathrm{~s}^{-1}$. From this, it can be inferred that the species responsible for the absorption was the same methylenic radical as observed in the reaction between 1 and the ${ }^{\circ} \mathrm{OH}$ radical $\left(\lambda_{\max } 420 \mathrm{~nm}\right)$. It is worth mentioning that the bleaching due to depletion of the parent (inset of figure 3) at $360 \mathrm{~nm}$ recovered during the time period of $5 \mathrm{~ms}$. One explanation of the recovery might be the most unlikely possibility of disproportionation of two methylenic radicals regenerating one molecule of $\mathbf{1}$. For better understanding, we carried out $\gamma$ radiolysis of $\mathbf{1}$ employing ${ }^{\circ} \mathrm{OH}$ radical as the reactant and measured the change in its absorption spectrum

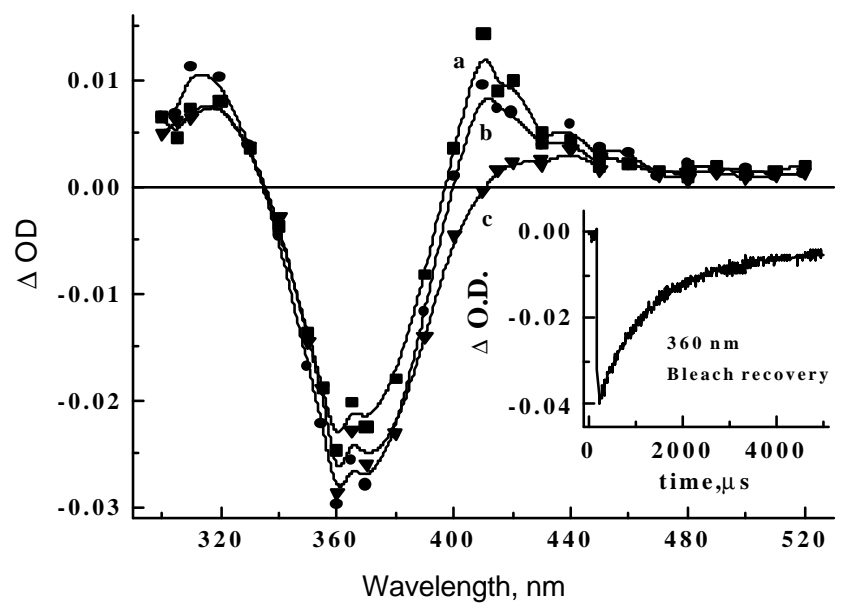

Figure 3. Transient absorption spectrum obtained from $\mathrm{N}_{2} \mathrm{O}$-saturated aqueous solution containing $\mathbf{1}\left(1.0 \times 10^{-4} \mathrm{~mol} \mathrm{dm}^{-3}\right)$ and $\mathrm{NaN}_{3}\left(1.0 \times 10^{-1} \mathrm{~mol} \mathrm{dm}^{-3}\right)$ at $p \mathrm{H} 8$ after the electron pulse at (a) $20 \mu \mathrm{s}$, (b) $50 \mu \mathrm{s}$ and (c) $200 \mu \mathrm{s}$. Inset: Typical oscilloscope traces for the bleach recovery at $360 \mathrm{~nm}$ obtained in the above reaction. 


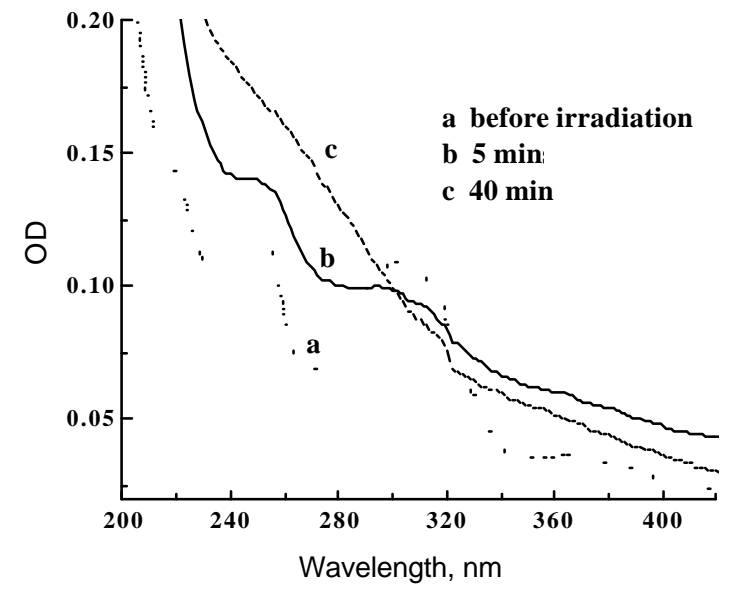

Figure 4. Steady-state absorption spectra obtained from an $\mathrm{N}_{2} \mathrm{O}$-saturated aqueous solution containing $1\left(5.0 \times 10^{-5} \mathrm{~mol} \mathrm{dm}^{-3}\right)$ at $p \mathrm{H} 7$ before and after $\gamma$-irradiation at a dose rate of $10 \mathrm{~Gy} / \mathrm{min}$ (a) before irradiation, (b) after 5 min irradiation and (c) after 40 min irradiation.

(figure 4). As evident from the figure, a new product with a strong absorbance around $360 \mathrm{~nm}$ was formed in the reaction which contributed significantly to the apparent bleach recovery.

3.3a Oxygen effect: The carbon-centred radicals are known to react at a very fast rate with $\mathrm{O}_{2}$ to form the corresponding peroxyl radical. ${ }^{9}$ Thus, to confirm that the reactive species $\left(\lambda_{\max } 410-420 \mathrm{~nm}\right)$ observed in the present study was indeed a carbon-centred radical, we examined its decay in the presence of $\mathrm{O}_{2}$ (figure not shown). A noticeable enhancement in the rate of decay of the species was evident, thereby confirming it to be the $\beta$-diketone methylenic radical as proposed earlier.

\subsection{Reaction with trichloromethylperoxyl radical}

The trichloromethylperoxyl radical $\left(\mathrm{Cl}_{3} \mathrm{COO}{ }^{\circ}\right)$ has been extensively used as a representative peroxyl radical for the inherent simplicity in performing the experiments and indeed, has been used earlier to study the free radical interaction between vitamins $\mathrm{E}$ and $\mathrm{C}^{13}$. The radical can be generated in aerated water/propan-2-ol/acetone $(50: 40: 10$ $v / v$ ) mixtures containing carbon tetrachloride by the following reactions.

$$
\begin{aligned}
& \mathrm{H}^{\bullet}, \text { or } \\
& { }^{\bullet} \mathrm{OH}+\left(\mathrm{CH}_{3}\right)_{2} \mathrm{CHOH} \rightarrow\left(\mathrm{CH}_{3}\right)_{2} \mathrm{C}^{\bullet} \mathrm{OH}+\mathrm{H}_{2} \text { or } \mathrm{H}_{2} \mathrm{O}, \\
& e_{\mathrm{aq}}{ }^{-}+\left(\mathrm{CH}_{3}\right)_{2} \mathrm{CO} \rightarrow\left(\mathrm{CH}_{3}\right)_{2} \mathrm{C}^{\bullet} \mathrm{O} \rightarrow\left(\mathrm{CH}_{3}\right)_{2} \mathrm{C}^{\bullet} \mathrm{OH}, \\
& \left(\mathrm{CH}_{3}\right)_{2} \mathrm{C}^{\bullet} \mathrm{OH}+\mathrm{CCl}_{4} \rightarrow\left(\mathrm{CH}_{3}\right)_{2} \mathrm{CO}+\mathrm{CCl}_{3}{ }^{-}+\mathrm{H}^{+} \mathrm{Cl}^{-}, \\
& \mathrm{CCl}_{3}{ }^{\bullet}+\mathrm{O}_{2} \rightarrow \mathrm{CCl}_{3} \mathrm{OO}^{\bullet} .
\end{aligned}
$$




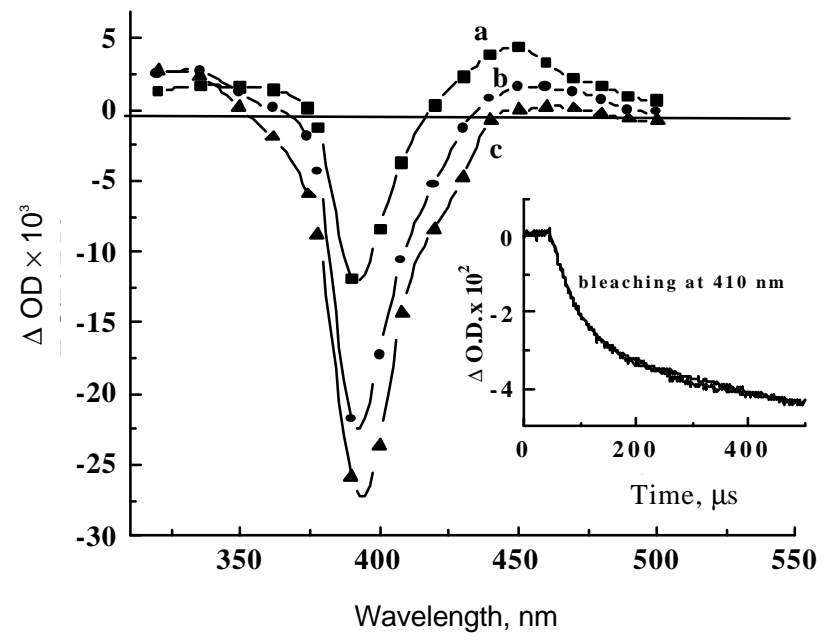

Figure 5. Transient absorption spectra obtained from an air-saturated aqueous solution (40\% propanol-2-ol, $10 \%$ acetone, $50 \%$ water) of $p \mathrm{H} 9.0$, containing 1 $\left(3 \times 10^{-4} \mathrm{~mol} \mathrm{dm}^{-3}\right)$ and $\mathrm{CCl}_{4}\left(1 \times 10^{-2} \mathrm{~mol} \mathrm{dm}^{-3}\right), 20(\mathrm{a}), 50$ (b) and $200 \mu \mathrm{s} \mathrm{(c)} \mathrm{after}$ the electron pulse. Inset: Typical oscilloscope traces recorded at $410 \mathrm{~nm}$ for the radical formed in the reaction of $\mathbf{1}\left(3 \times 10^{-4} \mathrm{~mol} \mathrm{dm}^{-3}\right)$ and $\mathrm{CCl}_{3} \mathrm{OO}{ }^{\bullet}$ radical at $p \mathrm{H} 9.0$ with $\left(2.5 \times 10^{-5} \mathrm{~mol} \mathrm{dm}^{-3}\right)$ and without ascorbic acid.

Compound 1 was found to react with $\mathrm{CCl}_{3} \mathrm{O}_{2}{ }^{-}$radical at $p \mathrm{H} 9$ to give transient absorptions at $450 \mathrm{~nm}$ (figure 5) with a bimolecular rate constant in the order of $10^{9} \mathrm{dm}^{3} \mathrm{~mol}^{-1} \mathrm{~s}^{-1}$. As the absorbance at $450 \mathrm{~nm}$ in figure 5 is low, the error in the measurement of rate constant may be greater than mentioned in the experimental section. Hence we feel it is reasonable to present the order of magnitude of the rate constant rather than exact numerical value. The species produced is probably the same carbon-centred radical obtained in both ${ }^{\circ} \mathrm{N}_{3}$ and ${ }^{\circ} \mathrm{OH}$ radical induced oxidation of $\mathbf{1}$. The shift in its absorption spectrum in the present case might be caused by the change in the reaction medium. Scheme 1 represents the oxidation reactions. It must be noticed (inset of figure 5) that there was no change in the bleaching signal in the presence and absence of ascorbic acid. Hence, the radical was not repaired by ascorbic acid, in agreement with the results of our earlier study on [6]-dehydrogingerdione. ${ }^{6}$ It must be noticed that the bleaching recovery that was evident in reaction with ${ }^{\circ} \mathrm{N}_{3}$ radical was not observed in this case. Possible reason is that the presence of oxygen in the case of $\mathrm{CCl}_{3} \mathrm{OO}^{\bullet}$ radicalinduced oxidation changes the fate of the radical produced.

\subsection{Inhibition of $\mathrm{Fe}^{2+}$-induced lipid peroxidation}

In unstimulated control experiments, little TBARS was formed $\left(A_{532}=0.06 \pm 0.01\right)$ in the rat brain homogenate. However, addition of ferrous iron and ascorbate triggered the lipid peroxidation leading to an increase in TBARS content $\left(A_{532}=0 \cdot 32 \pm 0 \cdot 01\right)$. The control experiments showed that $\mathbf{1}$ itself did not interfere with the absorption at $532 \mathrm{~nm}$ as its addition to a terminated reaction mixture did not change the TBARS absorption at $532 \mathrm{~nm}$. However, compound 1 inhibited lipid peroxidation in a concentration-dependent manner (figure 6) showing $>90 \%$ protection at a concentration of $5 \times 10^{-4} \mathrm{~mol} \mathrm{dm}^{-3}$. 


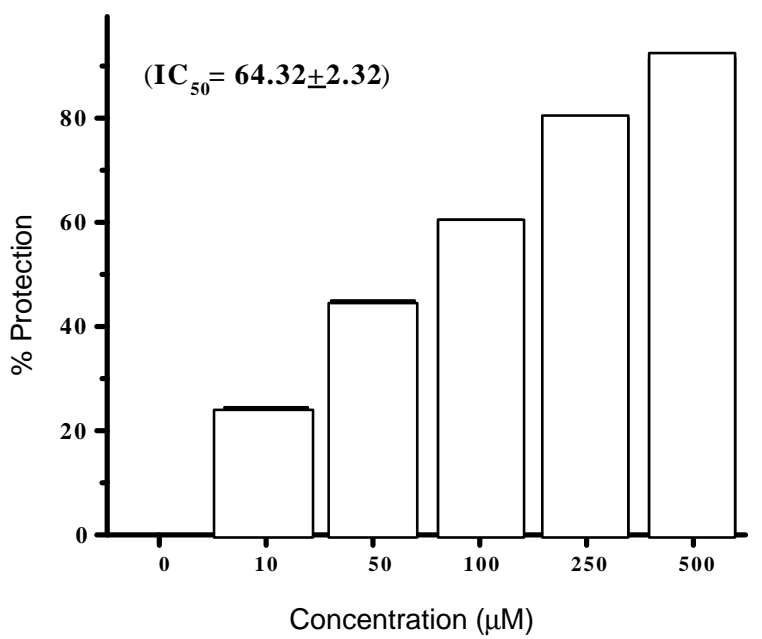

Figure 6. Inhibition of $\mathrm{Fe}^{2+}$-induced lipid peroxidation of rat brain homogenate by compound $\mathbf{1}$.

This result clearly demonstrates that $\mathbf{1}$ can scavenge not only $\mathrm{CCl}_{3} \mathrm{O}_{2}{ }^{\bullet}$ radicals having high redox potentials ${ }^{14}$ but also the biologically relevant lipid peroxyl radicals very efficiently.

\section{Conclusions}

The present study has demonstrated that $\beta$-diketones such as $\mathbf{1}$ can act as effective free radical scavengers in spite of being devoid of any phenolic group. The mode of their scavenging action for the free radicals is via hydrogen abstraction from the active methylene group of $\beta$-diketone moiety. As revealed from the pulse radiolysis experiment, $\mathbf{1}$, a model substrate of this class of compounds, can scavenge various oxidizing radicals efficiently. In addition, its biological efficacy as a non-phenolic antioxidant is also evident from its inhibitory activity against lipid peroxidation. Thus, a compound having a phenolic group as well as the above structural feature is anticipated to possess enhanced antioxidant activity. This may be the case with the curcuminoids.

\section{Acknowledgements}

The authors are grateful to Dr J P Mittal for his constant encouragement and support. We are also thankful to Shri V N Rao and his colleagues for valuable technical help.

\section{References}

1. Singh S V, Hu X, Srivastava S K, Singh M, Xia H, Orchard J L and Zaren H A 1998 Carcinogenesis 191357

2. Khafif A, Schantz S P, Chou T C, Edelstein D and Sacks P G 1998 Carcinogenesis 19419

3. Reddy B S, Kawamori T, Rao C V, Lubet R A, Steele V E and Kelloff G J 1979 Proc. Am. Assoc. Cancer Res. 39126

4. Kawamori T, Lubet R, Steele V, Kelloff G J, Kaskey R B, Rao C V and Reddy B S 1999 Cancer Res. $\mathbf{5 9} 597$ 
5. Samaha H S, Kelloff G J, Steele V, Rao C V and Reddy B S 1997 Cancer Res. 571301

6. Patro B S, Rele S, Chintalwar G J, Chattopadhyay S, Adhikari S and Mukherjee T 2002 Chem. Biochem. 3364

7. Jovanovic S V, Steenken S, Boone C W and Simic M G 1999 J. Am. Chem. Soc. 1219677

8. Ross L, Berclay C, Vinqvist M R, Mukai K, Goto H, Hashimoto Y, Tokunaga A and Uno H 2000 Org. Lett. 22841

9. Jovanovic S V, Boone C W, Steenken S, Trinoga M and Kaskey R B 2001 J.Am.Chem. Soc. 1233064

10. Mukherjee T 1997 Atomic, molecular and cluster physics (ed.) S A Ahmad (New Delhi: Narosa) pp. 299-316

11. Buxton G V and Stuart C R 1995 J. Chem. Soc. Faraday Trans. 91279

12. Joshi R, Adhikari S, Patro B S, Chattopadhyay S and Mukherjee T 2001 Free Radical Biol. Med. 301390

13. Packer J E, Slater T F and Willson R L 1979 Nature (London) 278737

14. Das T N, Dhanasekaran T, Alfassi Z B and Neta P 1998 J. Phys. Chem. A102 280 